\title{
Cost-Benefits of a Mobile, Trailer-Contained, Vibratory Finishing Decontamination Facility
}

\author{
R. F. Hazelton \\ M. W. McCoy
}

July 1982

Prepared for the U.S. Department of Energy under Contract DE-AC06-76RLO 1830

Pacific Northwest Laboratory Operated for the U.S. Department of Energy by Battelle Memorial Institute 


\title{
DISCLAIMER
}

This report was prepared as an account of work sponsored by an agency of the United States Government. Neither the United States Government nor any agency thereof, nor any of their employees, makes any warranty, express or implied, or assumes any legal liability or responsibility for the accuracy, completeness, or usefulness of any information, apparatus, product, or process disclosed, or represents that its use would not infringe privately owned rights. Reference herein to any specific commercial product, process, or service by trade name, trademark, manufacturer, or otherwise, does not necessarily constitute or imply its endorsement, recommenidation, or favoring by the United States Government or any agency thereof. The views and opinions of authors expressed herein do not necessarily state or reflect those of the United States Government or any agency thereof.

\author{
PACIFIC NORTHWEST I.ABORATORY \\ operated by \\ BATTELLE \\ for the \\ UNITED STATES DEPARTMENT OF ENERGY \\ under Contract DE-AC06-76RLO 1830
}

\begin{tabular}{|c|c|}
\hline \multicolumn{2}{|c|}{ Printed in the United States of America } \\
\hline \multicolumn{2}{|c|}{ Available from } \\
\hline \multirow{4}{*}{\multicolumn{2}{|c|}{$\begin{array}{c}\text { National Technical Information Service } \\
\text { United States Department of Commerce } \\
5285 \text { Port Roval Road } \\
\text { Springfield, Virginia } 22151\end{array}$}} \\
\hline & \\
\hline & \\
\hline & \\
\hline \multirow{2}{*}{\multicolumn{2}{|c|}{$\begin{array}{l}\text { NTIS Price Codes } \\
\text { Microfiche A01 }\end{array}$}} \\
\hline & \\
\hline \multicolumn{2}{|c|}{ Printed Copy } \\
\hline & Price \\
\hline Pages & Codes \\
\hline 001-025 & $\mathrm{A} 02$ \\
\hline 026-050 & $\mathrm{A} 03$ \\
\hline 051-075 & $\mathrm{A} 04$ \\
\hline $976-100$ & A05 \\
\hline $10:-125$ & A06 \\
\hline $126-150$ & A07 \\
\hline $151-175$ & $\mathrm{~A} 08$ \\
\hline $176-200$ & A09 \\
\hline $201-225$ & A010 \\
\hline $226-250$ & A011 \\
\hline $251-275$ & A012 \\
\hline $276-300$ & A013 \\
\hline
\end{tabular}


R. F. Hazelton

M. W. McCoy

Ju 1y 1982

Prepared for

the U.S. Department of Energy

under Contract DE-AC06-76RLO 1830

Pac if ic Northwest Laboratory Richland, Washington 99352 


\section{SUMMARY}

The objective of this study was to determine the cost-benefits of a vibratory finishing process, developed at Pacific Northwest Laboratory (PNL), which has been used successfully to remove a variety of transuranic (TRU) contaminants from surfaces of metallic and nonmetallic wastes. Once TRU contaminants are removed, the metallic and nonmetallic materials can be disposed of as lowlevel waste (LLW). Otherwise, these materials would be disposed of in geologic repositories.

This study provides an economic evaluation of the vibratory finishing process as a possible method for use in decontaminating and decommissioning retired facilities at Hanford and other sites. Specifically, the economic evaluation focuses on a scoping design for a mobile, trailer-contained facility, which could be used in the field in conjunction with decontamination and decommissioning operations. The costs for the facility are based, in part, on an assumption that no sectioning of contaminated materials is required beyond the optimum for geologic disposal. Optimal sectioning or size reduction of the waste is as yet undefined. The mobile facility would be classified as a low-inventory, nonreactor nuclear facility. Administrative controls would be required to keep its transuranic inventory below specified levels.

The capital cost of the mobile facility is estimated to be about $\$ 1.09$ million including contingency and working capital. Annual operating costs, including disposal costs, are estimated to be $\$ 440,000$ for processing about $6340 \mathrm{ft}^{3} / \mathrm{yr}$ of pre-sectioned, TRU-contaminated material. Combining the operating cost and the capital cost, annualized at a discount rate of $10 \%$, the total annual cost estimate is $\$ 602,000$. The unit cost for vibratory finishing is estimated to be about $\$ 11 / \mathrm{ft}^{3}$ of original reference glove box volume (Abrams et a1. 1980). All costs are in first quarter 1981 dollars. Although not directly comparable, the unit cost for the vibratory finishing process is very favorable when considered beside typical, substantially higher, unit costs for processing and geologically disposing of TRU-contaminated materials (Brown 1980; Abrams et a1. 1980). 
The latter process method cost includes costs for size reduction, whereas size reduction or sectioning costs are not included in costs for vibratory finishing.

Sensitivity analyses were made to determine the effect of varying several factors on the total annual and unit costs of vibratory finishing TRU-contaminated materials. Of the varied factors, operating cost had the largest effect on the total annual cost, whereas throughput had the greatest effect on unit cost within the range of variation evaluated. $A \pm 30 \%$ change in operating cost altered the total annual cost $\pm 22 \%$. A $\pm 30 \%$ change in throughput had little effect on the total annual cost because no modifications requiring expenditure were made to the facility, and labor, the largest element of operating cost, remained constant. However, a $30 \%$ increase in throughput lowered the unit cost $20 \%$, and a $30 \%$ decrease raised it $38 \%$. Annual savings that might be realized by vibratory finishing TRU-contaminated materials instead of geologic disposal would vary in the same manner as unit costs with changes in throughput.

The costs of vibratory finishing in a fixed facility would be less than those for a mobile facility, principally because the amount of labor could be reduced. A rough estimate for processing the same quantity of material in a fixed vibratory finishing facility, assuming it could be placed in available space in an existing building, indicated that the unit cost would be about $\$ 6.70 / \mathrm{ft}^{3}$ of the original reference glove box volume.

The probable accuracy of this study cost estimate is about $\pm 30 \%$. It is therefore recommended that a detailed cost estimate be prepared if a mobile facility is designed. 


\section{ACKNOWLEDGMENTS}

The cost-benefit study discussed in this report was sponsored by the U.S. Department of Energy as part of the project, "Decontamination and Decommissioning of Hanford Facilities--Technology." The authors thank J. M. Usher of the U.S. Department of Energy, Surplus Facilities Management Program Office, for $h$ is encouragement of this study.

The authors also gratefully acknowledge the information and assistance provided by the following individuals from Pacific Northwest Laboratory: R. P. Allen, R. B. Abrams, V. F. FitzPatrick, L. K. Fetrow, M. O. Lyso, L. D. Perrigo, and M. E. 01son. The technical and cost information and reviews are appreciated. 


\section{CONTENTS}

SUMMARY

ACKNOWLEDGMENTS

INTRODUCTION

CONCLUSIONS AND RECOMMENDATIONS

VIBRATORY FINISHING PROCESS DESCRIPTION

FACILITY DESCRIPTION

SERVICES

WORK AREAS OF PROCESS TRAILER .

FACILITY CAPITAL COST ESTIMATE

TRAILER COSTS

PROCESS EQUIPMENT COSTS .

EXCLUSIONS

WORK ING CAPITAL

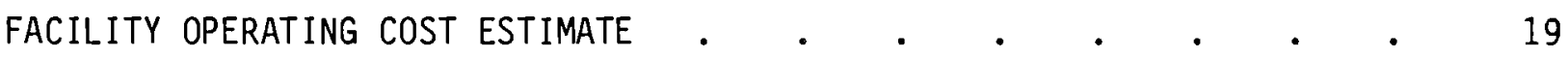

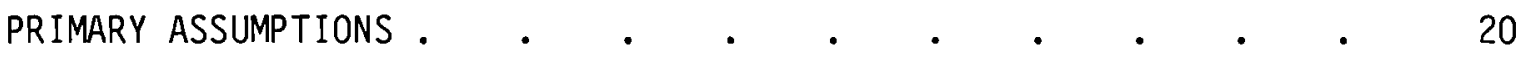

MIXED METALLiC AND NONMETALLIC WASTE PROCESSED ANNUALLY $\quad \cdot \quad$ • 21

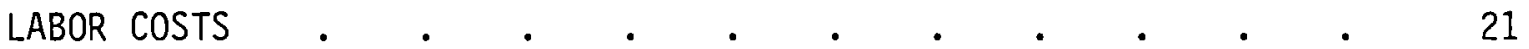

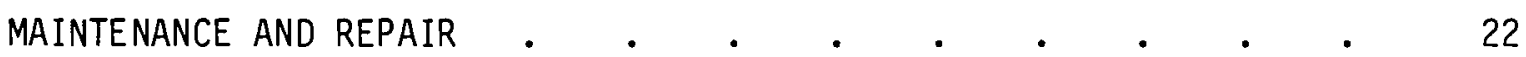

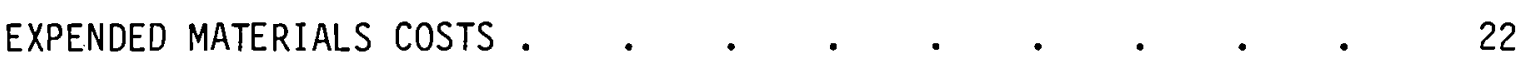

PROTECTIVE CLOTHING AND LAUNDRY COSTS

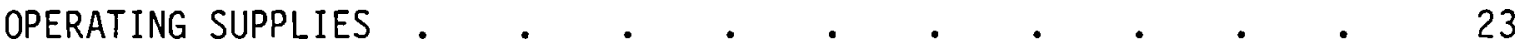

UTILITIES COST .

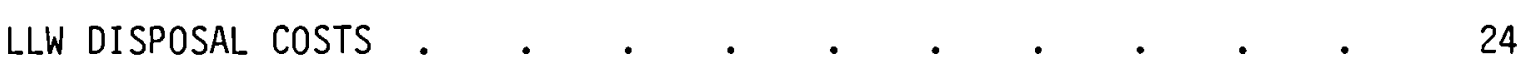




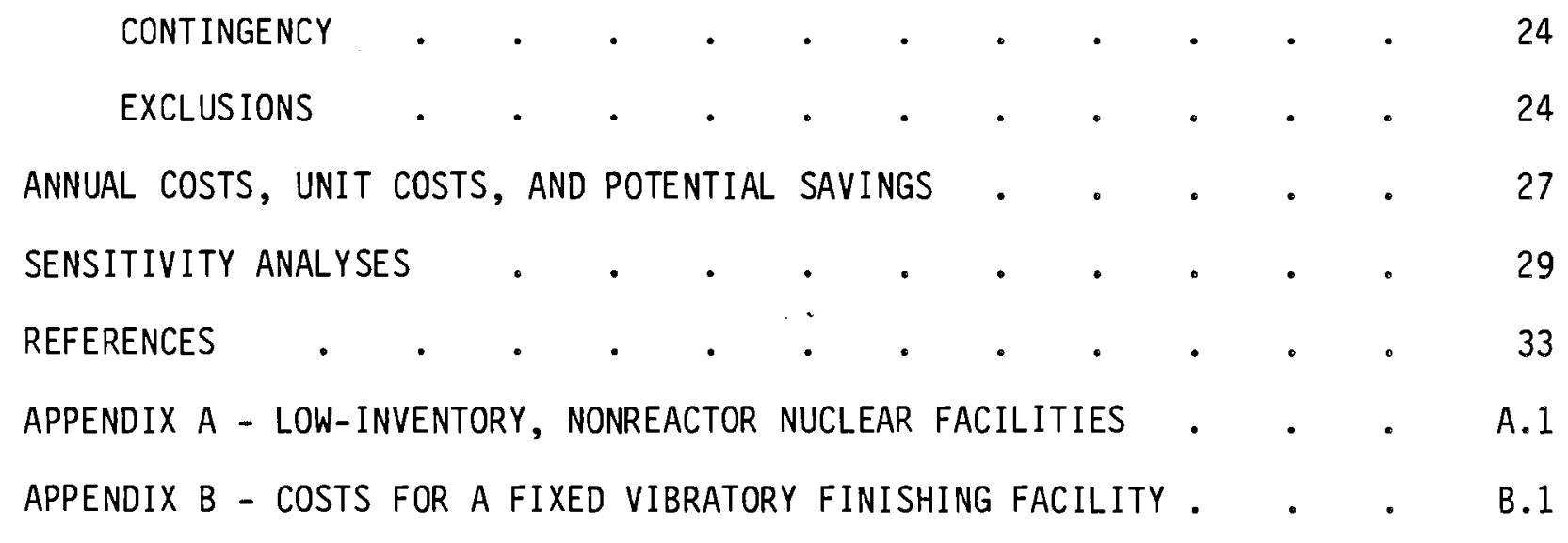


$\underline{\text { FIGURES }}$

1 Process Flow Diagram for Vibratory Finishing TRU Waste $\quad$ - 6

2 Vibratory Finishing Decontamination System . . . . . . 7

3 Annular Vibratory Finisher with $12-\mathrm{ft}^{3}$ Capacity $\quad$ • $\quad$ - 8

4 Plan View of the Mobile, Trailer-Contained, Vibratory

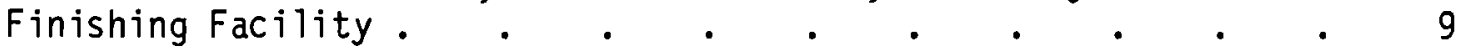

5 Perspective View of the Mobile, Trailer-Contained, Vibratory

Finishing Facility. $. \quad . \quad$.

\section{$\underline{\text { TABLES }}$}

1 Capital Cost Summary for Mobile Vibratory Finishing Facility . 13

2 Capital Cost Estimate for Trailers $\quad$. $\quad . \quad . \quad . \quad . \quad . \quad 14$

3 Capital Cost Estimate for Process Equipment . . . . . . 15

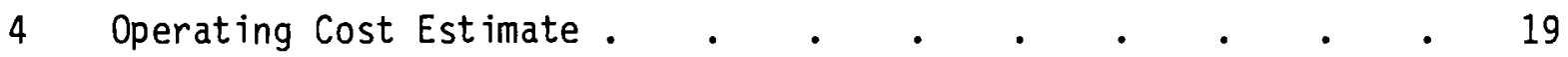

5 Costs and Effects of Varying Discount Rate . . . . . . . 28

6 Effects of Varying Throughput of TRU-contaminated Materials . 30

7 Effects of Varying Operating Cost . . . . . . . . 30

8 Effects of Varying Capital Cost $. \quad . \quad . \quad . \quad . \quad . \quad . \quad 31$

9 Effects of Varying Facility Life . . . . . . . . . . 32

A.1 Limits on Curie Inventory Quantities for Radionuclides in
Low-Inventory Facilities . . . . . . . A.2

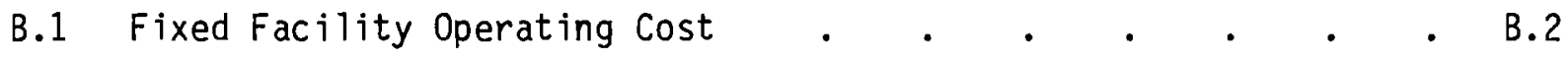




\section{INTRODUCTION}

Transuranic (TRU)-contaminated materials generated by nuclear operations are presently placed in interim storage to await availability of a permanent geologic repository. The amount of retrievable TRU-contaminated materials held in interim storage as of 1980 was estimated to be about $61,000 \mathrm{~m}^{3}$ (2.15 million $\left.\mathrm{ft}^{3}\right)$; an additional $85,000 \mathrm{~m}^{3}\left(3.0 \mathrm{million} \mathrm{ft}^{3}\right)$ was projected to be generated between the years 1980 and 2000 (U.S. DOE 1981). The estimated unit cost, if this waste is placed in interim storage, later retrieved, sorted, packaged, and disposed of in a central geologic repository, is about $\$ 200 / \mathrm{ft}^{3}$. This cost, the lowest for several processing options evaluated and reported by Brown (1980) and Abrams et al. (1980), is for processing new, stored, and buried transuranic wastes. An economic incentive exists to develop processes to decontaminate TRU-contaminated metallic and nonmetallic materials so that they can be disposed of as low-level waste (LLW) at substantially less cost, perhaps by an order of magnitude.

Vibratory finishing is a promising decontamination process (McCoy, Allen, and Arrowsmith 1980; McCoy, Arrowsmith, and Allen 1980) that has had rapid and successful development at Pacific Northwest Laboratory (PNL). In this process, adapted from one used in the metals finishing industry, contaminants are mechanically and chemically scoured from surfaces of metallic or nonmetallic materials in a vibrating annular tub. PNL studies have demonstrated that vibratory finishing is capable of decontaminating these materials to substantially less than $10 \mathrm{nCi} / \mathrm{g}$, the present maximum limit for disposal of the waste as LLW material. Based on the difference in disposal costs between LLW disposal and geologic disposal, vibratory finishing appears to offer considerable economic benefit.

The purpose of the task discussed in this report was to establish the cost-benefits of a vibratory finishing decontamination facility that can be used in the field in conjunction with decontamination and decommissioning operations to process TRU-contaminated material. The objective was accomplished by estimating capital and operating costs of vibratory finishing and 
LLW disposal and then comparing the overall cost with the cost of geologic disposal. All estimates are based on a scoping design facility since no detailed design engineering has been performed. Several alternatives for a mobile vibratory finishing facility with various processing capabilities have been envisioned. One concept, a trailer-contained unit, is evaluated in this report. The estimated costs given throughout this report are in first quarter 1981 dollars. The vibratory finishing facility would be classified as a lowinventory, nonreactor nuclear facility, which requires administrative control to limit its quantity of radionuclides.

This report covers the various aspects of the cost-benefit evaluation, and includes descriptions of the vibratory finishing procedure and the mobile facility. It also gives details on estimated capital costs, operating costs, and resultant annual cost and potential savings. Since each of these costs involves some uncertainty, a sensitivity analysis is provided to show the effect of variation of some cost or processing elements. The appendices contain a discussion of low-inventory, nonreactor facilities and costs for a fixed vibratory finishing facility. 


\section{CONCLUSIONS AND RECOMMENDATIONS}

The capital cost of the mobile, trailer-contained, vibratory finishing facility is estimated to be about $\$ 1.09$ million including allowances for contingency and working capital. The yearly operating cost is estimated to be about $\$ 440,000$ for processing about $6340 \mathrm{ft}^{3}$ of pre-sectioned TRU-contaminated waste. With the capital cost annualized, using an 11-year life for the facility and a discount rate of $10 \%$, the total annual cost to operate the facility is est imated to be about $\$ 602,000$. The unit cost for vibratory finishing presectioned materials in a mobile facility and LLW disposal is about $\$ 95 / \mathrm{ft}^{3}$ of reduced volume. This is equivalent to a cost of $\$ 11 / \mathrm{ft}^{3}$ of original glove box volume, based upon the reference glove box described by Abrams et al . (1980). All estimated costs are in first quarter 1981 dollars and are based on a scoping design.

The vibratory finishing and LLW disposal costs are based on the assumption that the facility would be classified as a low-inventory, nonreactor nuclear facility and that no additional costs for sectioning mixed TRU-contaminated materials would be incurred over that which could produce a minimum volume of material for geologic disposal. The extent, and consequently the costs, of optimal sectioning or waste size reduction for geologic disposal is as yet undefined. If, after the extent of this sectioning is established, any further sectioning is required before vibratory finishing, the incremental costs will have to be charged to the vibratory finishing operations.

Sensitivity analyses were made to determine the effects of changes in discount rate, throughput, operating cost, capital cost, and facility life upon the total annual cost and the unit cost for processing TRU-contaminated materials. Of the changes evaluated, those for operating cost and throughput had the most significant effects. Changing the operating cost $\pm 30 \%$ altered both the total annual cost and unit cost $+22 \%$. Changes in throughput substantially affected the unit cost but had little effect on the total annual cost because the principal elements of this cost, capital and labor, are essentially fixed. An increase in throughput of $30 \%$ lowered the unit cost $20 \%$; a $30 \%$ decrease 
raised the unit cost $38 \%$. Annual savings that might be realized by vibratory finishing would vary the same as unit cost with change in throughput. Changes in discount rate, capital cost, and facility life produced smaller changes in the total annual cost and unit cost. An increase in discount rate from $10 \%$ of the base case to $20 \%$ raised the annual and unit costs by $14 \%$; a $\pm 30 \%$ change in capital cost raised or lowered the total annual and unit costs $\pm 8 \%$; cutting the facility life in half increased the annual and unit costs by $15 \%$.

Although a mobile, trailer-contained, vibratory finishing facility has been evaluated in this study, it is but one of several alternatives that have been envisioned. Other alternatives should be evaluated in future studies for cost effectiveness, especially in the ir use of labor, the major expense for the trailer-contained facility. For example, because of reduced labor requirements, costs for vibratory finishing in a fixed facility would be less than those for the mobile facility. A rough estimate for processing the same quantity of presectioned material in a fixed facility, assuming space in an existing building were available, indicated that the unit cost would be about $\$ 58 / \mathrm{ft}^{3}$ as compared with $\$ 95 / \mathrm{ft}^{3}$ of reduced volume, or $\$ 6.70 / \mathrm{ft}^{3}$ as compared with $\$ 11 / \mathrm{ft}^{3}$ of the original glove box volume.

The probable accuracy of this study est imate is about $\pm 30 \%$. Therefore, a detailed cost estimate with a higher accuracy is recommended if a mobile vibratory finishing facility is designed. 


\section{VIBRATORY FINISHING PROCESS DESCRIPTION}

The vibratory finishing process, adapted from one used in the metals finishing industry for deburring metal parts, combines mechanical scrubbing and chemical action in a vibratory finisher to scour TRU contaminants from surfaces of sectioned-to-size metallic and nonmetallic materials. The principal processing occurs in a vibrating tub that contains metal media of various shapes. These media are capable of entering corners and crevices of the waste. A liquid chemical compound, which both loosens and rinses contaminants from surfaces of the waste, is recirculated from a storage and settling tank to the vibratory tub. A batch of mixed metallic and nonmetallic materials is scoured in the vibrating tub for about $1 \mathrm{hr}$.

After the metal media is removed by screening, the decontaminated material is rinsed with water, dried, monitored for radiation, and placed into drums for transport to an LLW disposal site. The chemical solution is settled and filtered during recycling, and spent solution is sent from the mobile facility to the nuclear operations site evaporator. Evaporator bottoms and spent filter elements, which together contain the TRU contaminants, are then placed into a drum along with Portland cement for solidification. These materials are mixed in the drum by placing the drum on a roller and allowing the cement paste to solidify. The solidified materials containing the TRU contaminants are then suitable for disposal.

The TRU-contaminated metallic and nonmetallic materials received for vibratory finishing in the mobile facility would be partially decontaminated before sectioning but still contaminated in excess of $10 \mathrm{nCi} / \mathrm{g}$. These materials would be decontaminated by vibratory finishing to less than $10 \mathrm{nCi} / \mathrm{g}$, probably as low as $0.1 \mathrm{nCi} / \mathrm{g}$. Most measurable contamination would be removed; al1 smearable contamination would be removed (McCoy, Arrowsmith, and Allen 1980).

A block flow diagram for the overall process is shown in Figure 1. A schematic drawing of the principal elements of the system and how they operate 


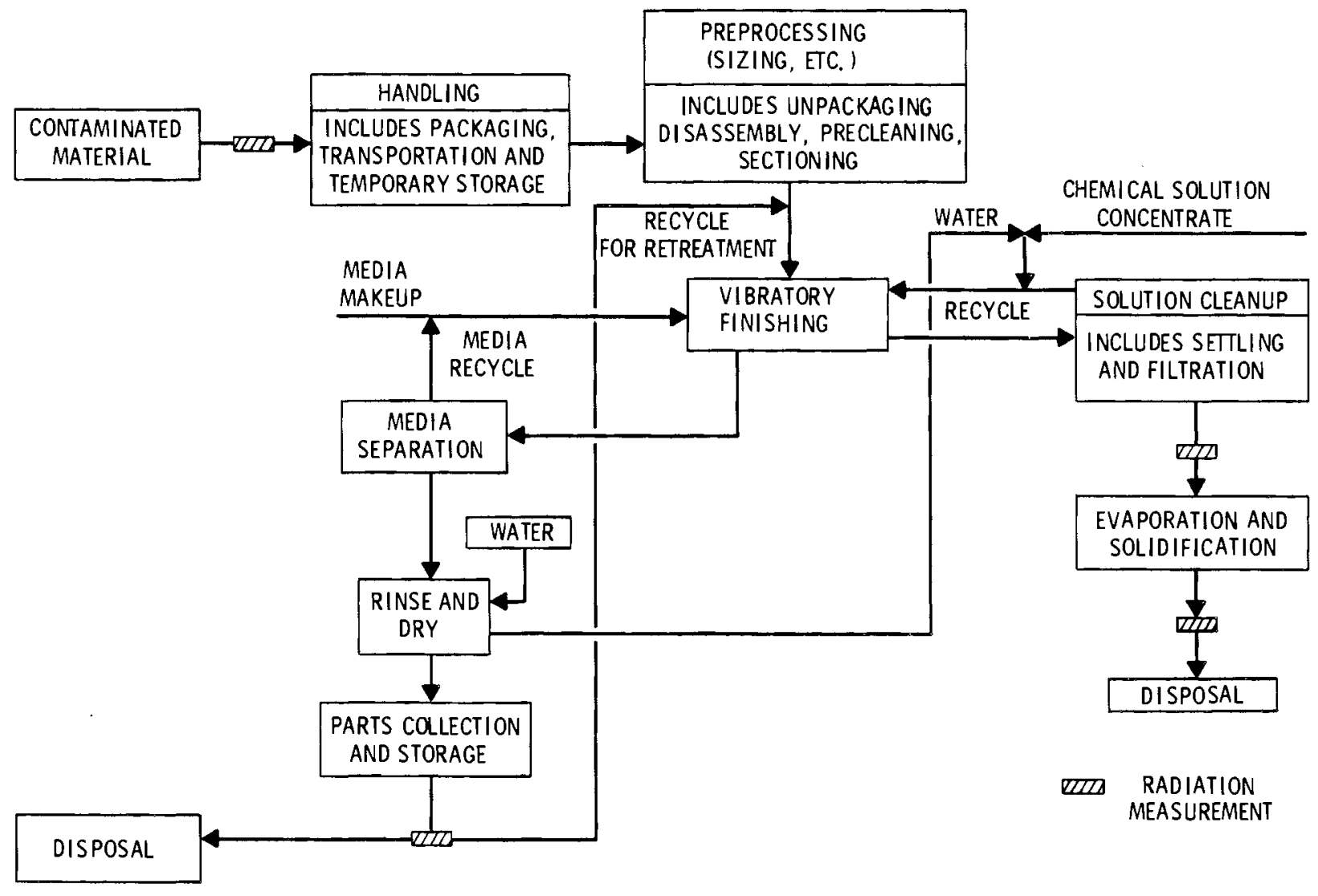

FIGURE 1. Process Flow Diagram for Vibratory Finishing TRU Waste

is presented in Figure 2. A $5.25-\mathrm{ft}$ diameter, $12-\mathrm{ft}^{3}$ annular vibratory finisher, which could be used in the facility in a modified version, is shown in Figure 3; the normal frequency of the apparatus is about 1200 vibrations/ minute. 


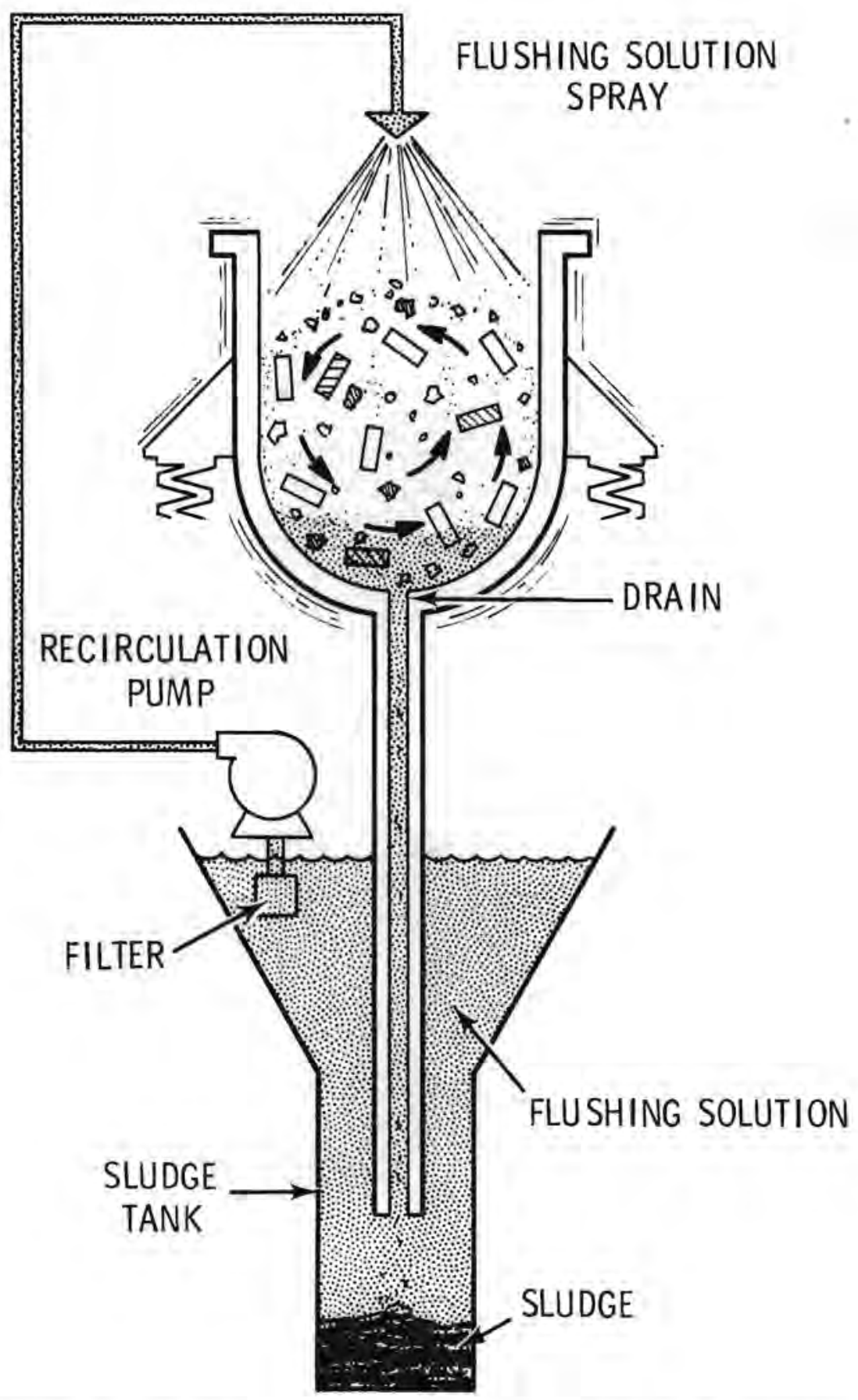

FIGURE 2, Vibratory Finishing Decontamination System 


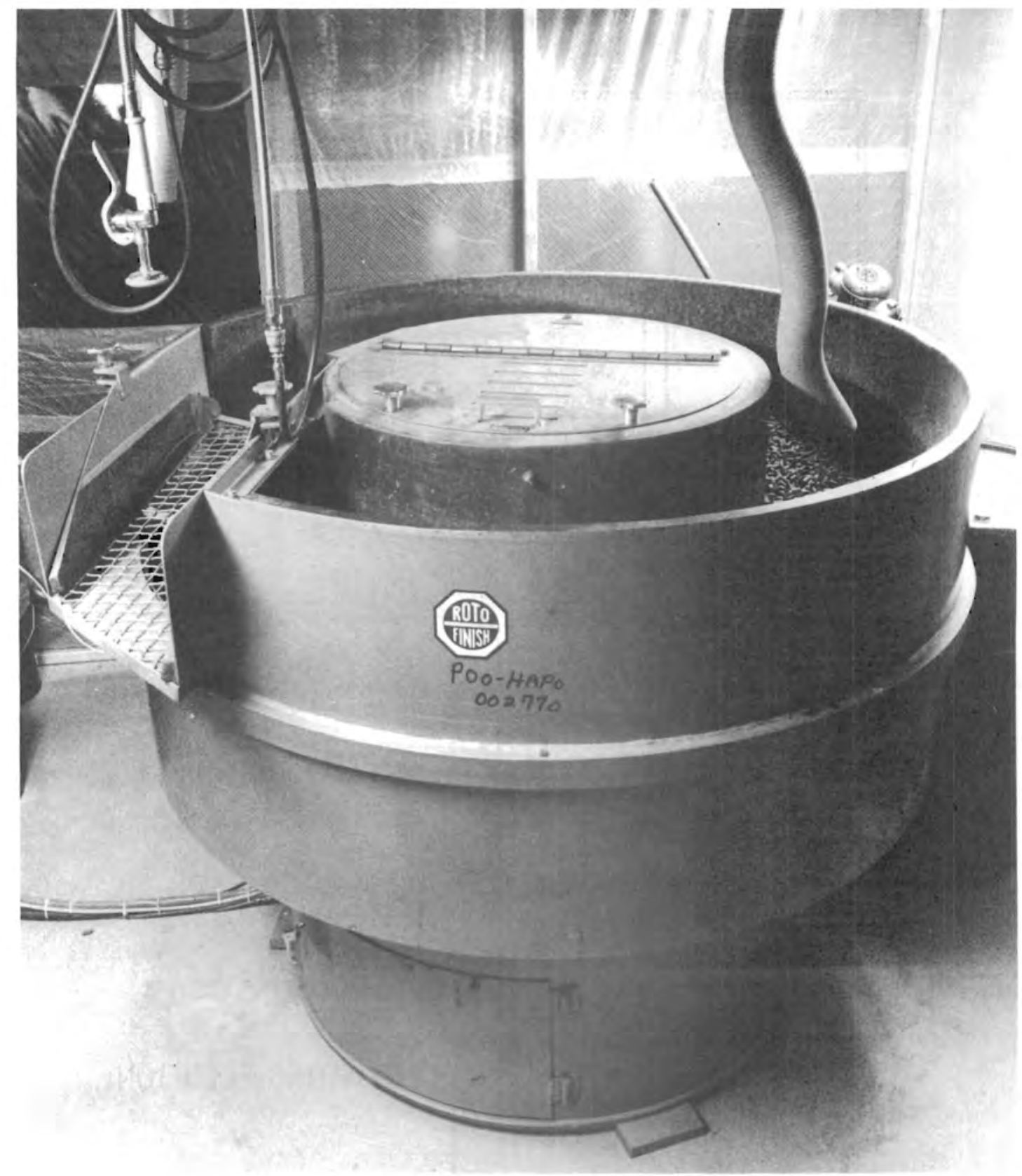

FIGURE 3. Annular Vibratory Finisher with 12-ft ${ }^{3}$ Capacity 


\section{FACILITY DESCRIPTION}

The mobile vibratory finishing facility would consist of two trailers; one to contain the processing system, the other to contain the support services such as heating, ventilation, and air conditioning (HVAC) and HEPA filtration. The support trailer also would have a change room, a storage area for supplies, and space for an emergency power generator. One possible arrangement for a vibratory finishing process trailer is shown in a plan view in Figure 4 and in a perspective view in Figure 5 . Each trailer would be about $10 \mathrm{ft}$ wide and $40 \mathrm{ft}$ long; the height with in each trailer would be about $8 \mathrm{ft}$. The trailers would be lined inside with stainless steel sheeting to permit easy decontamination should an unlikely event occur which dispersed radioactive contaminants within. The trailers would be designed to avoid or minimize contamination and to make cleaning easier. Design techniques that would be used are given by Perrigo (1970).

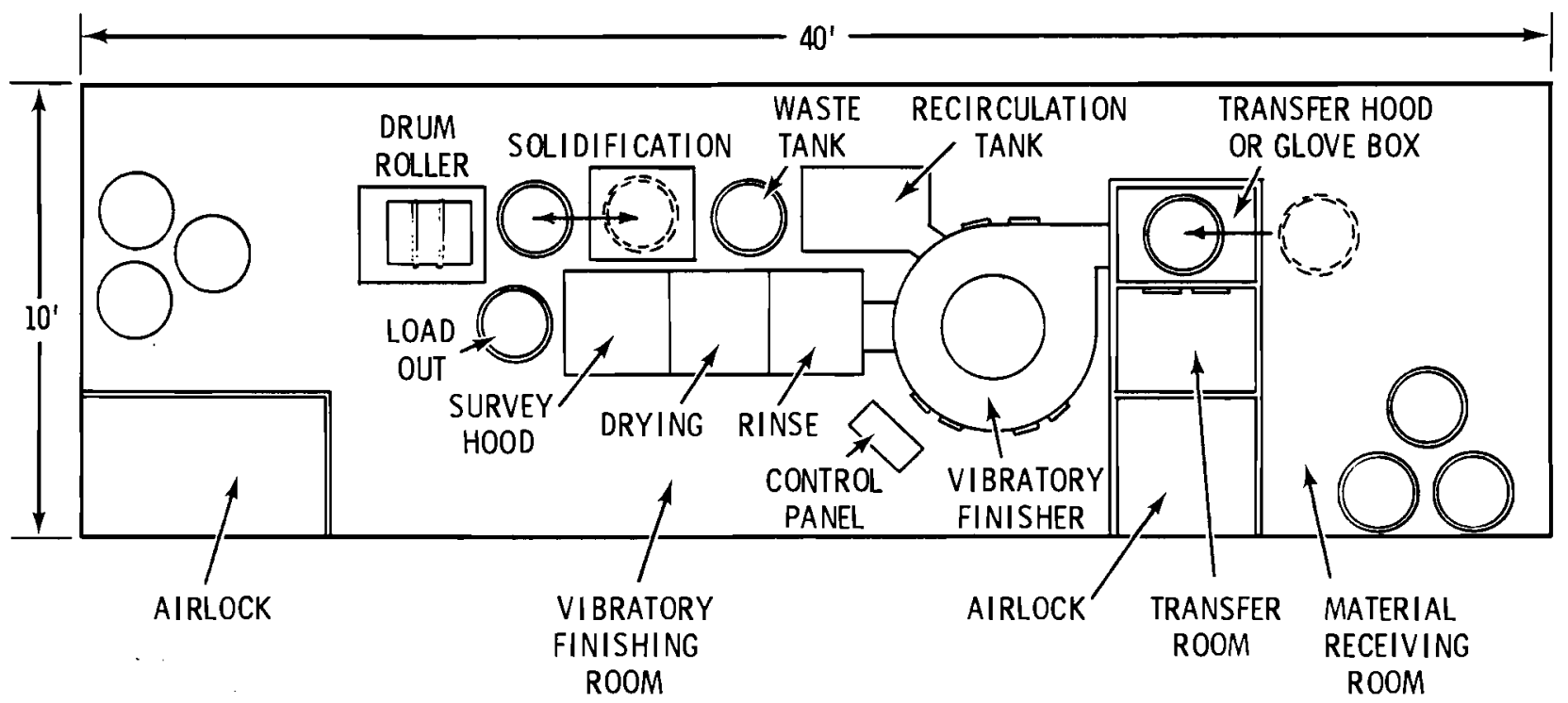

FIGURE 4. Plan View of the Mobile, Trailer-Contained, Vibratory Finishing Facility 


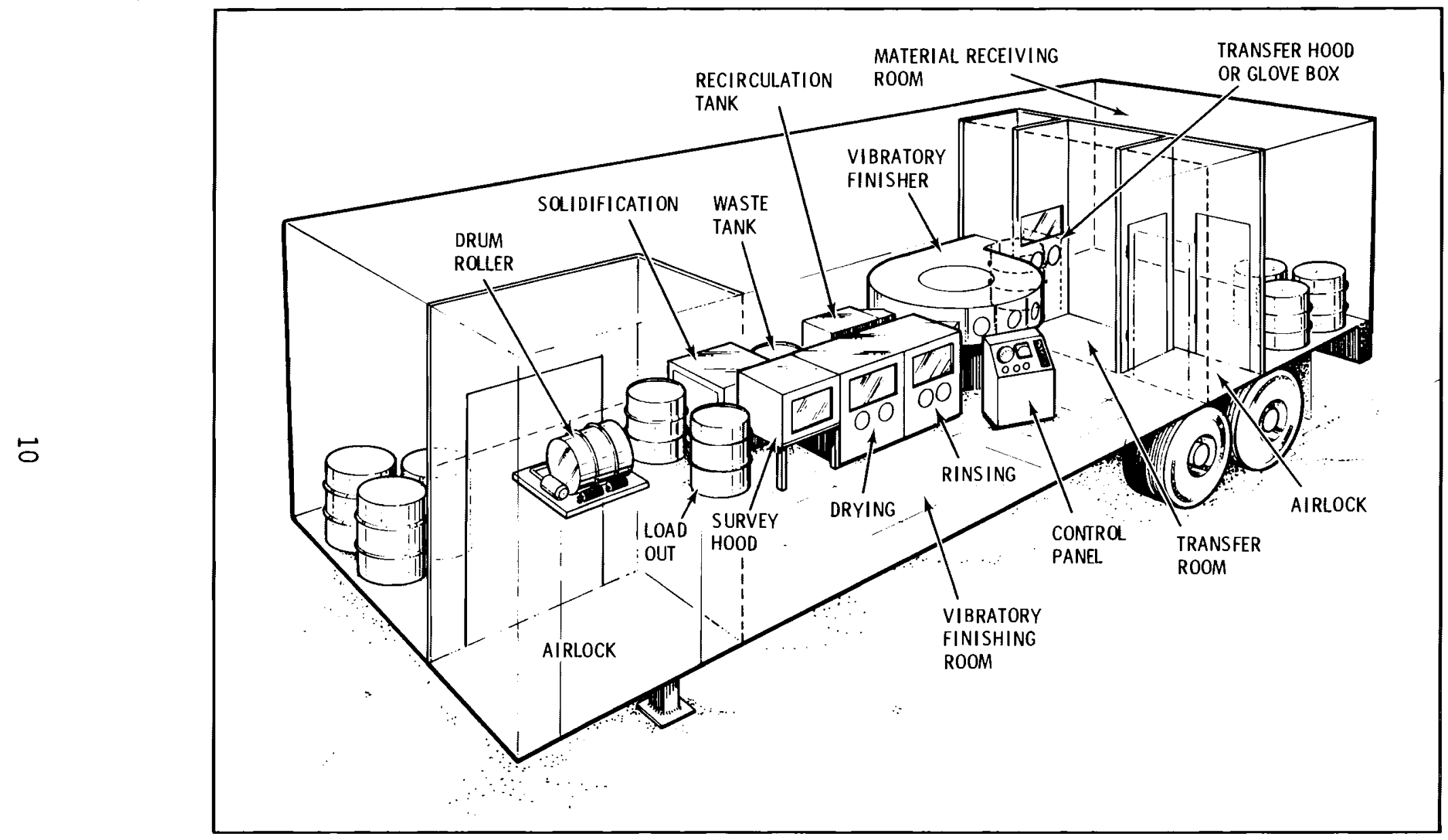

FIGURE 5. Perspective View of the Mobile, Trailer-Contained, Vibratory Finishing Facility 


\section{SERVICES}

The trailers would be provided with easy hookup to electrical and water services at the site of the decontamination work. All external lighting and other security services would be furnished by the operation site.

Fresh, conditioned air would be supplied by the support trailer. Air would be HEPA filtered before entering and after being exhausted from the process trailer. An entry and an exhaust HEPA filter stage would be installed with in the process trailer to prevent external dispersal of any airborne contaminants should slight overpressuring of the trailer and reverse air flow occur. Air would be monitored continuously by automatic radiation instruments. Delivery and exhaust ducts would distribute and collect air at several locations.

Halon ${ }^{\oplus}$ fire protection systems or equivalent also would be provided in each trailer. Few combustibles would be in the facility at one time. The combustibles principally would be plastic bags used to contain sectioned metallic and nonmetallic parts within 55-gal drums.

\section{WORK AREAS OF PROCESS TRAILER}

The trailer would have several areas or rooms for material receiving, waste transfer, and vibratory finishing operations. In addition, two airlocks would be provided for personnel to enter or leave the facility. Although at a negative pressure compared to ambient, the airlocks and the material-receiving area would be maintained at a slightly higher pressure than other rooms of the trailer to maintain contamination control integrity.

\section{Material-receiving Room}

The material-receiving room would be at the rear of the trailer. It would have a large door to permit receiving and storage of TRU waste in sealed drums. A 2-ton hoist and a small roller conveyor would be furnished for moving drums between storage and the waste transfer room.

\footnotetext{
Trademark of the Allied Chemical Corporation.
} 
Waste Transfer Room

The radioactive-material waste transfer room would be equipped with a hood having a balanced air system that would allow some air to come from the room and some to come directly from the outside through the HVAC system. The air velocity at the face of the hood would be $150 \mathrm{ft} / \mathrm{min}$. After a sealed drum is conveyed into the transfer room, the two rooms would be isolated from each other before a drum is opened. A drum would be opened by a fully protected operator dressed in radiation zone work clothing, who would transfer TRU waste from the drum to the vibratory fin isher tub through an opening in the tub cover. The opening to the vibratory finisher would be closed and the drum resealed once the waste is transferred.

Vibratory Finishing Operations Room

The vibratory finisher, with its controls and support equipment, would be in the largest room of the trailer. The room al so would contain the rinse and dry system for the decontaminated waste; a filter; a liquid waste solidification system, including a hydraulic drum roller and lift; and a small conveyor to handle drums filled with either decontaminated, cleaned and dried parts, or solidified materials. The drum roller is provided as a stand-by item since exhausted chemical solution usually would be sent to a liquid waste handing system at the work site for concentration by evaporation and solidification of the evaporator concentrate. A second hoist, like that in the receiving room, would be located in the vibratory finishing room to allow movement and temporary storage of filled LLW drums.

\section{Radiation Monitoring Instrumentation}

Radiation monitoring instruments would be placed throughout the facility. Extra instruments would be provided so that a set could be undergoing calibration or maintenance at any time without affecting operations. The instruments would include portable alpha meters, CP beta-gamma survey units, P-11 low-level beta-gamma meters, and neutron survey units. 


\section{FACILITY CAPITAL COST ESTIMATE}

The estimated capital cost for the entire facility is $\$ 1.09$ million, as shown in Table 1. This cost is for two trailers, installed process equipment, and working capital. The probable accuracy of the study estimate is in the range of $\pm 30 \%$.

TABLE 1. Capital Cost Sumary for Mobile Vibratory Finishing Facility

Cost Basis: First Quarter 1981 Dollars

$\begin{array}{lr}\text { Trailers (2) } 10 \mathrm{ft} \times 40 \mathrm{ft} & \$ 500,000 \\ \text { Process Equipment } & 521,000 \\ \text { Working Capital } & 73,000 \\ \text { Total Capital Cost } & \$ 1,094,000\end{array}$

(Note: The number of significant figures shown is for computational completeness; it is not to imply that accuracy of the estimate is to nearest thousand dollars.)

\section{TRAILER COSTS}

A breakdown of the trailer costs is given in Table 2. (a) Two unequipped but custom-built, 10-ft-wide, 40-ft-long, 8-ft-high (internally) trailers would cost $\$ 80,000$. Stainless steel lining and partitions cost $\$ 42 ; 000$. Costs of electrical services, the HVAC system (including a heat pump, ducts, and HEPA filters), a Halon ${ }^{\circledR}$ fire protection system (or equivalent), continuous air monitoring apparatus, and miscellaneous equipment are $\$ 68,000$. Engineering, construction overhead, and contractor profit would be $\$ 160,000$. Since this is a scoping design estimate, a contingency of $40 \%$ was taken, giving a cost of $\$ 140,000$; total cost for the trailers is $\$ 500,000$.

(a) Estimate developed by M.E. 01son, PNL Project Management, based upon information provided by Vitro Engineering Corporation. Basic trailer costs obtained from Freuhauf Trailers. 
TABLE 2. Capital Cost Estimate for Trailers

Cost Basis: First Quarter 1981 Dollars

\begin{tabular}{|c|c|}
\hline Equipment & Cost \\
\hline Trailer A $(10 \times 40 \times 8 \mathrm{ft})$ & $\$ 40,000$ \\
\hline Trailer $B(10 \times 40 \times 8 \mathrm{ft})$ & 40,000 \\
\hline \multicolumn{2}{|l|}{ Stainless steel liner } \\
\hline \multicolumn{2}{|l|}{2 trailers } \\
\hline $\begin{array}{l}\text { Stainless steel partitions } \\
400 \mathrm{ft}^{2} \text { @ } \$ 40 / \mathrm{ft}^{2}\end{array}$ & 16,000 \\
\hline Electrical & 15,000 \\
\hline \multicolumn{2}{|l|}{ HVAC - heat pump, duct work } \\
\hline $\begin{array}{l}\text { Fire protection and miscellaneous } \\
\text { A. Subtotal, Direct Costs }\end{array}$ & $\frac{23,000}{\$ 200,000}$ \\
\hline \multicolumn{2}{|l|}{ Engineering @ $35 \% \mathrm{~A}$} \\
\hline B. Subtotal & $\$ 270,000$ \\
\hline \multicolumn{2}{|l|}{ Overhead and Profit @ $35 \%$ B } \\
\hline C. Subtotal & $\$ 360,000$ \\
\hline \multicolumn{2}{|l|}{ Contingency @ $40 \% \mathrm{C}$} \\
\hline (rounded to nearest $\$ 10 \mathrm{~K}$ ) & 140,000 \\
\hline TOTAL & $\$ 500,000$ \\
\hline
\end{tabular}

\section{PROCESS EQUIPMENT COSTS}

Table 3 lists the estimated installed equipment costs, which consist of direct costs for purchasing the equipment and intalling it in the trailer. The purchase costs are based upon:

- actual purchases for PNL vibratory finishing system

- estimates given to PNL for equipment in a preliminary design stage

- prices in a mechanical equipment supply catalog (McMaster and Carr 1979) 
TABLE 3. Capital Cost Estimate for Process Equipment Cost Basis: First Quarter 1981 Dollars

\begin{tabular}{lr}
\multicolumn{1}{c}{ Equipment } & Cost \\
\cline { 2 - 2 } Vibratory finisher & $\$ 61,000(a)$ \\
Vibratory finisher media & 5,100 \\
Roller conveyors (2) & 800 \\
Hoists (2) & 13,000 \\
Filter system & 4,200 \\
Rinsing/drying system & 36,000 \\
Drum roller & 5,600 \\
Waste tank & 5,000 \\
Hoods & 32,000 \\
Radiation monitoring instrumentation & 12,500 \\
Spare parts & 19,000 \\
A. Subtotal, Direct Installed & \\
$\quad$ Costs, rounded & $\$ 194,000$ \\
Startup, 12\% of direct costs of & \\
process equipment and trailer & 47,000 \\
B. Subtotal & $\$ 241,000$ \\
Engineering, 35\% of A, Direct & \\
Installed Cost, rounded & \\
C. Subtotal & \\
Contractor overhead, supervision, & $\$ 311,000$ \\
other indirects, and profit; & \\
35\% of C & $\$ 110,000$ \\
D. Subtotal & $\$ 421,000$ \\
Contingency, 25\% of D (rounded) & 100,000 \\
TotAL & $\$ 521,000$ \\
\end{tabular}

(a) Direct installed cost of equipment. 
- prices in a laboratory equipment catalog (American Scientific Products 1981)

- estimated costs in books on estimating standards (Richardson Engineering Services 1980 and 1981).

The direct costs for installation are based upon factors given by Guthrie (1974) or upon data by Richardson Engineering (1981). Purchased equipment costs were escalated as necessary to first quarter 1981 dollars using Marshall and Swift equipment cost indexes published in each biweekly issue of Chemical Engineering Magazine.

The costs for the vibratory finisher, vibratory finishing media, drum roller, and radiation monitoring equipment are based upon PNL purchases. A circular vibratory finisher similar to that shown in Figure 3 was purchased for about $\$ 33,000$ in 1979 . The cost in Table 3 reflects an estimated modification cost $(20 \%)$ to give the apparatus glove box capabilities. An installation factor of 1.3 was used. About $11 \mathrm{ft}^{3}$ of steel vibratory media, costing $\$ 420 / \mathrm{ft}^{3}$ in 1980 , would be used. A drum roller, which cost $\$ 3900$ in early 1980 , could be used for solidifying spent liquids with Portland cement. Again, the installation factor used was 1.3.

Estimates were provided to PNL for a filter unit to be used to polish recirculating chemical solution from the vibratory finisher and a rinsing/ drying system for decontaminated metallic and nonmetallic materials. Installation factors of 1.4 and 1.5 , respectively, were used to give the costs in Table 3. The costs for a 50 to 100 gal liquid neutralization waste tank, used for adjusting the $\mathrm{pH}$ of spent vibratory finishing chemical solution, were estimated similarly. This waste tank would be equipped with an agitator, flush system, spray nozzles, and a pH instrument. Because these systems are not yet well defined, the cost estimates are rough.

Roller conveyors would be used at the receiving and discharge ends of the process train. The roller conveyors are $22 \mathrm{in}$. wide and 5 to $10 \mathrm{ft}$ long with a 2-in. roller spacing, and are capable of carrying $300 \mathrm{lb}$ per roller. The two conveyors would cost about $\$ 400$ (McMaster-Carr catalog). Installation would double this figure. 
Hoods would be used for transferring the contaminated materials into the vibratory finisher, for surveying decontaminated material after $r$ insing and drying, and for processing spent liquids. Laboratory equipment catalog prices for stainless steel perchloric acid hoods, equipped with wash-down features, were used for this pre-design estimate. A 1.4 installation factor was used.

Two hoists of 2-ton capacity each would be placed at either end of the process trailer to move heavy drums and other material. By means of the Richardson Engineering (1981) standards, an installed cost of $\$ 13,000$ was est imated.

An allowance of $5 \%$ of direct costs for the trailer and process equipment, or $\$ 19,000$ is provided in the estimate for spare parts that would be needed for equipment repair or replacement. Also, during startup, equipment may have to be altered or replaced. To cover these startup costs, $\$ 47,000$ or $15 \%$ of direct costs is provided.

Engineering and contractor costs, including overhead and profit, are estimated to be about $\$ 180,000$. The same percentages of direct costs as those used for the trailer cost estimates were used. A contingency of $25 \%$ was used for the process equipment instead of $40 \%$ because more is known about the equipment that will be used than about the trailer configuration. The estimated total capital cost for installing the process equipment is about $\$ 521,000$.

\section{EXCLUSIONS}

Costs of the following are excluded from this estimate:

- Site development - depends on circumstances ranging from the availability of a work area to the need for a concrete pad and utility lines.

- Emergency backup power - provided by nuclear plant.

- Electrical and water services - provided by nuclear plant.

- Outside lighting - provided by nuclear plant. 
- Security, accountability, and criticality safety controls - provided by operators within a security zone; all drums of contaminated metallic and nonmetallic materials are already partially decontaminated before sectioning and pre-screened for fissile material content before placement into drums.

WORKING CAPITAL

Working capital consists of cash kept on hand for monthly payments of operating expenses. Peters and Timmerhaus (1968) state that most chemical plants use an initial working capital amounting to 10 to $20 \%$ of the total capital investment. Others (e.g., Lyda 1972) break down working capital into amounts for raw materials and supplies, finished product inventories, accounts receivable less accounts payable, wages, etc. for periods ranging from 15 to 45 days. For this study, an allowance equivalent to 2 months operating costs $(\$ 73,000)$ was taken. This allowance falls between the $10 \%$ fraction of capital and that obtainable using the periodic requirements of the individual working capital components. Values of finished product inventories and accounts receivable would not be of concern for a DOE project. 


\section{FACILITY OPERATING COST ESTIMATE}

The annual operating costs for the trailer-contained, vibratory finishing facility are estimated to be about $\$ 440,000$ (first quarter 1981 dollars). A breakdown of costs is given in Table 4 for processing 259,000 lb of waste annually. The operating costs are based upon several assumptions, including the amount of TRU-contaminated metallic and nonmetallic materials processed.

\section{TABLE 4. Operating Cost Estimate}

Cost Basis: First Quarter 1981 Dollars

Base Case

Material processed: 862 300-1b drums/yr $259,000 \mathrm{lb} / \mathrm{yr}$ $6340 \mathrm{ft}^{3} / \mathrm{yr}-179 \mathrm{~m}^{3} / \mathrm{yr}$ (reduced volume)

Operation time: $\quad 44 \mathrm{wk} / \mathrm{yr}$

Labor

Cost

Maintenance and repairs $\$ 213,000$

Process Materials

Chemical concentrate 60,000

Metal vibratory fin isher media 600

Filter cartridges

5,100

Portland Type 2 cement 2,000

Drums (55-ga1) 300

Protective clothing and laundry

17,500

Operating supplies

4,500

Utilities

10,000

Water

Electricity

negligible

LW disposal

3,300

TRU geologic disposal

24,000

Subtotal (rounded)

12,000

Contingency, 25\%

$\$ 352,000$

Total Operating Cost 


\section{PRIMARY ASSUMPTIONS}

The primary assumptions used in preparing the operating cost estimate are:

- Facility will process contaminated material 44 weeks per year. The remaining weeks of the year will encompass downtime for repair, holidays, and moving the trailers from one site to another.

- Operation: 1 shift per day, 5 days per week

- Contaminated metallic and nonmetallic waste processed

- $30 \mathrm{ft}^{2}$ of waste per batch for $12 \mathrm{ft}^{3}$ vibratory finisher.

- 5 batches processed per day, allowing 1/4 hr for feeding the vibratory finisher, $1 \mathrm{hr}$ for operation, and $1 / 4 \mathrm{hr}$ for cleaned material discharge.

- average thickness of material: $3 / 16$ in.

- material all stainless steel with density of 0.29 lb/in. ${ }^{3}$

- 300 lb of waste per 55-gal drum.

- Vibratory finishing compound

- rate of diluted solution recycled to unit: $20 \mathrm{gph}$.

- diluted solution: 0.5 - 1\% concentrate; remainder, demineralized water.

- waste solution: $8 \mathrm{gph}$ of the dilute solution, which would be sent to the liquid waste handling system of the visited facility for concentration by evaporation and solidification of the evaporator bottoms.

- Filter cartridges: two $2 \times 10$-in. filter cartridges used for every $6 \mathrm{hr}$ of operation. When exhausted, these cartridges would be placed into a drum along with evaporated liquid waste residue for solidification. A drum would be used for solidification of 23 gal of dilute solution. A drum ready for disposal would weigh about $600 \mathrm{lb}$. 
- Labor: 2 nuclear technicians, full time; 1 radiation monitor, 1/2 time; 1 supervisor, $1 / 4$ time.

- Sectioning: assumed at no cost for preparation of material for vibratory finishing since equivalent sectioning may be done to reduce volume of material sent to geologic disposal.

\section{MIXED METALLIC AND NONMETALLIC WASTE PROCESSED ANNUALLY}

The weight of mixed waste processed in each batch, using the above assumptions, is $235 \mathrm{lb}$; this waste is chiefly sectioned stainless steel parts. This amount is based upon experience gained at PNL in operating a vibratory finisher. Since area, weight, and shipping volume for a material are indirectly related, the following annual amount is an approximation. With 235 lb per batch, 5 batches per day, 5 days per week, and 44 weeks per year for operation (at 1 shift per day), a total of 259,000 lb would be processed annually. The number of 55-gal drums containing 300 lb of waste each (a typical weight at PNL) would be 862 each year. The material is assumed to be carefully packed into drums to give a packed density of about $40 \mathrm{lb} / \mathrm{ft}^{3}$ based on the metal weight and the drum volume. The volume of the drums is equivalent to $6340 \mathrm{ft}^{3}$ (reduced volume) of waste per year, or the volume of waste that would have to be disposed of. (a)

\section{$\underline{\text { LABOR COSTS }}$}

Two nuclear technicians would conduct the operations of the vibratory finishing facility on a full-time basis. Although not needed for the

(a) The volume of a given weight of metal waste is variable as it depends upon the shape, random arrangement, and other factors for individual pieces within a waste collection. Waste volume can be affected by rearrangement, sectioning, melting, or other processing. This has been illustrated by Copeland and Heestand (1980). In their study, they took a random sample $(218 \mathrm{~kg})$ of mixed metal scrap, containing $40 \%$ aluminum, $35 \%$ stee 1 , and lesser percents of other metals from a scrap bin and reduced th is volume from $1.60 \mathrm{~m}^{3}\left(56.5 \mathrm{ft}^{3}\right)$ to $0.395 \mathrm{~m}^{3}\left(14 \mathrm{ft}^{3}\right)$ by mechanical sectioning, then to $0.0497 \mathrm{~m}^{3}\left(1.75 \mathrm{ft}^{3}\right)$ by melting into ingots and slag. Apparent bulk densitjes calculated from their data are, respectively, $136 \mathrm{~kg} / \mathrm{m}^{3}, 552 \mathrm{~kg} / \mathrm{m}^{3}$, and $4160 \mathrm{~kg} / \mathrm{m}^{3}\left(8.50 \mathrm{lb} / \mathrm{ft}^{3}, 34.4 \mathrm{lb} / \mathrm{ft}^{3}\right.$, and $\left.260 \mathrm{lb} / \mathrm{ft}^{3}\right)$. 
operations, the second technician is required for safety within the isolated facility. A fixed, unisolated facility would not have this requirement since the operation may be integrated with others. The labor cost rate including fringe benefits and overhead is assumed to be $\$ 34 / \mathrm{hr}$ for each technician. This rate is an approximation for that of the labor grade that might be used at the Hanford Site. A radiation monitor would survey operations frequently; a supervisor, who would have other assignments, would check work a few times a day. These labor costs are $\$ 34 / \mathrm{hr}$ and $\$ 50 / \mathrm{hr}$, respectively. Considering the manpower assumptions and assuming $5 \%$ additional cost for overtime, the annual cost for labor would be $\$ 213,000$.

\section{MAINTENANCE AND REPAIR}

An allowance of $6 \%$ of process equipment trailer costs is assumed for maintenance and repairs. The annual cost would be about $\$ 60,000$.

\section{EXPENDED MATERIALS COSTS}

The chemical concentrate used in the dilute chemical solution costs about $\$ 6.80 / g a 1$. The vibratory finisher will operate about $5 \mathrm{hr} /$ day; the rest of a shift would be used for loading or unloading the machine. The dilute solution having $1 \%$ concentrate is expended at a rate of $8 \mathrm{gph}$. At that rate, the annual cost of concentrate would be about $\$ 600 / \mathrm{yr}$.

Only a small amount of vibratory finishing media, a hardened steel, is anticipated to be lost due to wear or carried out with decontaminated material. Because the steel media is self-cleaning, no permanent radionuclide contamination is foreseen and replacement of the media for this cause should be infrequent. Replacement would be based upon an otherwise uncorrectable decrease in the system's decontamination efficiency. An annual allowance of $\$ 5100$, which is equivalent to the cost of media to fill the vibratory finisher, is provided.

Two filter elements would be used daily and disposed of by solidification along with spent chemical solution. The annual cost is estimated at $\$ 2000$ with each element priced at $\$ 5.30$. 
About 8800 gal of spent chemical solution is produced yearly by processing $6340 \mathrm{ft}^{3}$ of TRU-contaminated material. The waste liquid would be sent to the waste liquid handling system of the visited nuclear facility, and would be concentrated 20:1 by evaporation and solidified in 55-gal drums. The solidified waste containing the TRU contaminants would be disposed of in a geologic repository. Spent filter elements would be solidified and disposed of along with the concentrated liquid. Electricity required for evaporation would be about 23,000 kWh annual1y. Twenty-two 55-gal D0T-17H drums and 80 94-1b sacks of Portland Type 2 cement are required for solidification. The annual costs for drums and cement are about $\$ 400$ and $\$ 300$, respectively. The solidified waste also would be geologically disposed of; the unit cost of $\$ 2600 / \mathrm{m}^{3}$ (Brown 1980) gives an annual disposal cost of $\$ 12,000$. The costs for electricity and drums are included in the totals for these items in Table 4. The cement and geologic disposal costs are listed individually.

Assuming the same number of drums would be used for waste metal as those received, 862 drums would be used annually at a cost of about $\$ 17,100$. The total drum cost, including that for solidification would be $\$ 17,500$.

\section{PROTECTIVE CLOTHING AND LAUNDRY COSTS}

Hanford Site laundry costs for radiation worker coveralls and other protective clothing are about $\$ 0.47$ per $1 b$, or about $\$ 1.10$ per change. The annual cost for laundry, based upon about four changes of clothes per worker per day, would be about $\$ 4500$.

\section{OPERATING SUPPLIES}

The cost of operating supplies is assumed to be about $1 \%$ of capital cost, excluding working capital, or about $\$ 10,000$.

\section{UTILITIES COST}

Demineralized water is used for rinsing processed waste and chemical solution makeup. The annual use is estimated to be about 10,000 gal. Since process water costs about $\$ 3.00 / 1000$ gal, the total water cost is negligible. 
The following amounts of electricity are estimated as being used annually in the facility:

$\begin{array}{lr}\text { HVAC and HEPA filtration } & \frac{\mathrm{kWh} / \mathrm{yr}}{105,700} \\ \text { Lighting } & 5,600 \\ \text { Vibratory finishing } & 7,700 \\ \text { Rinse-dry system } & 13,000 \\ \text { Evaporation } & 23,000 \\ \text { Drum roller-solidification } & \frac{1,100}{156,100} \\ \quad \text { TOTAL } & \end{array}$

Since this is an order-of-magnitude estimate it is assumed that $160,000 \mathrm{kWh}$ are used annually. The total electricity cost at about $\$ 0.02$ per kWh would be $\$ 3200$ annua $11 y$.

\section{LLW DISPOSAL COSTS}

At the Hanford Site, the cost to dispose of LLW in drums was about $\$ 2.75$ to $\$ 3.75 / \mathrm{ft}^{3}$ in mid-1980. With this cost adjusted to the first quarter 1981 , the annual cost to dispose of 862 drums of decontaminated metallic and nonmetallic materials would be $\$ 24,000$. Other wastes such as rags would be disposed of, but the amount is comparatively small so their disposal cost is excluded.

\section{CONTINGENCY}

A contingency allowance of $25 \%$ of the subtotal of operating costs is provided to cover unknown costs that may arise.

\section{EXCLUSIONS}

A number of possible cost items are excluded from the estimate as they may be highly variable and unpredictable and chargeable to other accounts. These are: 
- Taxes and insurance - These costs are not applicable for a governmentowned facility. For a private facility these costs could amount to about $2 \%$ of total capital.

- Security, accountability, and criticality control operations - These functions will be provided by the nuclear site generating the waste to be processed.

- Forklift operations external to the facility and other costs of delivery and removal of wastes from the facility.

- Facility decontamination costs should an improbable accident occur that dispersed radionuclides throughout the facility.

- Costs to move trailers from site to site and set up at new sites.

- Environmental impact statements - All liquids, HEPA filters, and other materials possibly containing radionuclides would be removed from the facility and the facility would be cleaned and released before transit.

- Transit security - Security would not be needed on the highway because the facility would be prepared to meet low specific activity (LSA) requirements, a DOT shipping category. A Radiation Shipment Report (RSR) would be used for transit at the Hanford Site. 


\section{•}


ANNUAL COSTS, UNIT COSTS, AND POTENTIAL SAVINGS

Annual costs, including capital and operating costs, of vibratory finishing followed by LLW disposal can be determined using the technique given by Grant, Ireson, and Leavenworth (1976). They give the following equation to calculate annual cost for capital investment, or capital recovery:

$$
C R=(P-L)(A / P)_{i \star}, n+L i *
$$

where $C R$ is annual cost of capital recovery; $P$ is the first cost of a structure; $n$ is the facility's useful life; $L$ is prospective net salvage value at the end of $n$ years, $A$ is an end-of-period payment or receipt; $(A / P)_{i \star}, n$ is the capital recovery factor obtained from compound interest tables; and $i$ is the discount rate or minimum attractive rate of return.

In this calculation, $L$ was used to include recoverable working capital and salvage value, which was estimated at $5 \%$ of initial fixed capital cost, or $\$ 51,000$. The IRS allows 11 years $(n)$ to depreciate a chemical or process-type facility so this number was used as facility life. Discount rates, i*, of 5 , 10,15 , and $20 \%$ were used. Capital recovery factors were obtained from tables in Grant et al. (1976). The annual costs of capital recovery, facility operating cost, total annual costs and costs per unit volume are given in Table 5.

Using a 10\% discount rate for the base case, which will be used in the following discussion on sensitivity, the annual capital cost is $\$ 162,000$ for a facility life of 11 years. This cost, coupled with the annual $\$ 440,000$ operating costs, gives a total annual cost of $\$ 602,000$. With about $6340 \mathrm{ft}^{3}$ of sectioned metallic and nonmetallic material processed each year, the total annual cost for vibratory finishing and LLW disposal is equivalent to a unit cost of $\$ 95 / \mathrm{ft}^{3}$ of reduced volume. This is equivalent to a cost of $\$ 11 / \mathrm{ft}^{3}$ of the original glove box volume. (a)

(a) The ratio of original volume to sectioned or reduced volume is based on a reference glove box, which is a $4 \times 4 \times 8$ - $\mathrm{ft}$ unit with a storage volume of $128 \mathrm{ft}^{3}$. The metallic surface area is about $120 \mathrm{ft}^{2}$ and the corresponding solid volume is about $0.88 \mathrm{ft}^{3}$. The unit has plastic side and top panels (Abrams et al. 1980). 
TABLE 5. Cost and Effects of Varying Discount Rate

Cost basis:

Material Processed:

Operation Time:
First quarter 1981 dollars $6340 \mathrm{ft}^{3} / \mathrm{yr}$ (reduced volume) $40 \mathrm{wk} / \mathrm{yr}, 1$ shift/day

Annual

Operating Cost

$\$ 440,000 \quad \$ 440,000$

Discount Rate

\begin{tabular}{l}
$10 \%$ \\
$5 \% \quad$ (Base Case) $15 \% \quad 20 \%$ \\
\hline
\end{tabular}

Annual

Capital Cost

123,000

162,000

$\underline{204,000}$

$\underline{249,000}$

Total Annual Cost

$\$ 563,000$

$\$ 602,000$

$\$ 644,000$

$\$ 689,000$

Unit Cost,

$\$ / \mathrm{ft}^{3}$, Reduced

Volume

89

95

102

109

\% Change in

Total Annual Cost

$-6$

7

14

$\%$ Change in

Unit Cost

$-6$

7

14

This unit cost, which excludes costs for sectioning or size reduction, indicates that there may be potential for substantial savings by vibratory finishing TRU-contaminated materials and disposing of the materials as LLW. The unit cost for geologic disposal has been estimated to be about $\$ 200 / \mathrm{ft}^{3}$ of original volume (Abrams et al. 1980). However, a clear comparison cannot be made directly because the unit cost for geologic disposal includes costs for some size reduction, whereas the unit cost for vibratory finishing does not. As stated earlier, it was assumed for this evaluation that the vibratory finishing facility would receive pre-sectioned material. 


\section{SENSITIVITY ANAL YSES}

A sensitivity analys is is a means of evaluating the effects of uncertainty on investment by determining how the profitability varies as the parameters are varied that affect economic evaluation results (Stermole 1980). For further discussions of sensitivity, see Stermole (1980) or Grant, Ireson, and Leavenworth (1976).

Sensitivity analyses were made in this evaluation to determine the effects of varying discount rate, throughput, operating cost, capital cost, and facility life upon total annual cost and upon unit cost for vibratory finishing TRUcontaminated materials. In addition, a rough sensitivity analys is was made to determine the effect of having the vibratory finishing system located in the available space of an existing building rather than in a mobile facility.

As shown in Table 5, lowering the discount rate to $5 \%$ from the base case of $10 \%$ decreases both the annual cost and unit costs by $6 \%$; raising the discount rate to $15 \%$ and $20 \%$, respectively, increases the annual and unit costs by $7 \%$ and $14 \%$. Changes in throughput of $+30 \%$ have no substantial effect upon total annual cost, as shown in Table 6 . However, the unit cost $\left(\$ / \mathrm{ft}^{3}\right)$ is affected markedly, ranging from a decrease of $20 \%$ for an increase in throughput of $30 \%$ to an increase of about $38 \%$ for a decrease in throughput of $30 \%$. The reason for these effects is that the annual capital cost is constant regardless of throughut, and operating costs for this range of variance are nearly constant. The bulk of operating cost is for labor, which would be the same in each case, assuming that on ly one work shift is used; only the costs for processing materials and waste disposal vary with throughput.

A variance in operating cost of $\pm 30 \%$ directly increases or reduces the annual cost $\pm 22 \%$, when the annual capital cost is held constant. A variance in annual capital cost, being but $27 \%$ of the base case total annual cost, has less of an effect; the annual cost varies $+8 \%$ with changes in capital costs of $\pm 30 \%$. The un it costs vary by the same percentages with changes in operating and capital costs. These effects are shown in Tables 7 and 8. 
TABLE 6. Effects of Varying Throughput of TRU-contaminated Materials (Same bases as Table 5)

\begin{tabular}{|c|c|c|c|c|c|}
\hline & \multicolumn{5}{|c|}{ Change in Throughput } \\
\hline & $+30 \%$ & $+15 \%$ & Base Case & $-15 \%$ & $-30 \%$ \\
\hline Throughput, $\mathrm{ft}^{3} / \mathrm{yr}$ & 8,240 & 7,290 & 6,340 & 5,390 & 4,440 \\
\hline $\begin{array}{l}\text { Annual } \\
\text { Operating Cost }\end{array}$ & $\$ 461,000$ & $\$ 450,000$ & $\$ 440,000$ & $\$ 430,000$ & $\$ 419,000$ \\
\hline Annual Capital Cost & 162,000 & 162,000 & 162,000 & 162,000 & 162,000 \\
\hline Total Annual Cost & $\$ 623,000$ & $\$ 612,000$ & $\$ 602,000$ & $\$ 592,000$ & $\$ 581,000$ \\
\hline $\begin{array}{l}\text { Unit Cost, } \$ / \mathrm{ft}^{3} \\
\text { Reduced Volume }\end{array}$ & 76 & 84 & 95 & 110 & 131 \\
\hline $\begin{array}{l}\% \text { Change in } \\
\text { Total Annual Cost }\end{array}$ & 3 & 2 & - & -2 & -3 \\
\hline $\begin{array}{l}\% \text { Change in } \\
\text { Unit Cost }\end{array}$ & -20 & -12 & - & 16 & 38 \\
\hline
\end{tabular}

TABLE 7. Effects of Varying Operating Cost (Same bases as Table 5)

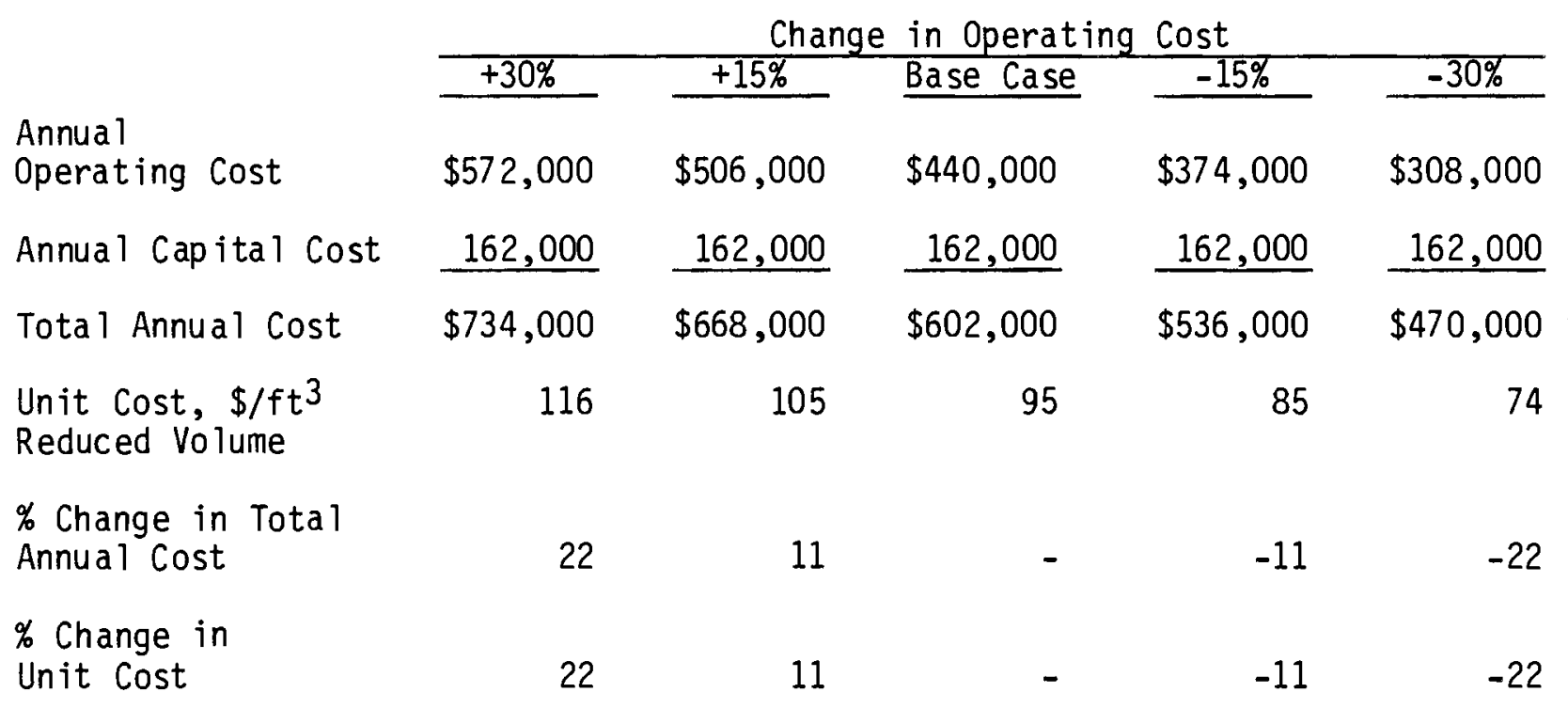


TABLE 8. Effects of Varying Capital Cost (Same bases as Table 5)

\section{Change in Capital Cost}

\begin{tabular}{|c|c|c|c|c|c|}
\hline & $+30 \%$ & $+15 \%$ & Base Case & $-15 \%$ & $-30 \%$ \\
\hline $\begin{array}{l}\text { Annual } \\
\text { Operating Cost }\end{array}$ & $\$ 440,000$ & $\$ 440,000$ & $\$ 440,000$ & $\$ 440,000$ & $\$ 440,000$ \\
\hline Annual Capital Cost & 211,000 & 186,000 & 162,000 & 138,000 & 113,000 \\
\hline Total Annual Cost & $\$ 651,000$ & $\$ 626,000$ & $\$ 602,000$ & $\$ 578,000$ & $\$ 553,000$ \\
\hline $\begin{array}{l}\text { Unit Cost, } \$ / \mathrm{ft}^{3} \\
\text { Reduced Volume }\end{array}$ & 103 & 99 & 95 & 91 & 87 \\
\hline $\begin{array}{l}\% \text { Change in Tota } 1 \\
\text { Annual } 1 \text { Cost }\end{array}$ & 8 & 4 & - & -4 & -8 \\
\hline $\begin{array}{l}\% \text { Change in } \\
\text { Unit cost }\end{array}$ & 8 & 4 & - & -4 & -8 \\
\hline
\end{tabular}

A facility life of 11 years has been used for this study but could decrease with advances in technology or for other reasons. Therefore, the effect of cutting the life of the facility in half is shown in Table 9. Both the total annual cost and the unit cost for vibratory finishing would increase by $15 \%$ due to a $54 \%$ increase in annual capital cost caused by the decrease in facility life. Although actual unit costs for a comparative geologic disposal process have not been determined, possible savings by vibratory finishing would be affected similarly.

Rough costs for vibratory finishing in a fixed facility are developed in Appendix B. Assuming that the same amount of TRU-contaminated materials would be processed as that for the mobile facility, the unit cost using the fixed facility would be $\$ 58 / \mathrm{ft}^{3}$ of reduced volume $\left(\$ 6.70 / \mathrm{ft}^{3}\right.$ of the original reference glove box volume) as compared with $\$ 95 / \mathrm{ft}^{3}\left(\$ 11 / \mathrm{ft}^{3}\right.$ of the original glove box volume). The fixed facility costs are not optimized. Most of the unit cost reduction results from reducing labor costs. 
TABLE 9. Effects of Varying Facility Life (Same bases as Table 5)

\begin{tabular}{lcr} 
& \multicolumn{2}{c}{ Facility Life } \\
\cline { 2 - 3 } & $\frac{5-1 / 2 \text { Years }}{\$ 440,000}$ & $\frac{11 \text { Years }}{(\text { Base Case })}$ \\
Annual Operating Cost & $\frac{250,000}{\$ 440,000}$ & 162,000 \\
Annual Capital Cost & $\$ 690,000$ & $\$ 602,000$ \\
Total Annual Cost & 109 & - \\
Unit Cost, $\$ / \mathrm{ft}^{3}$, & & - \\
Reduced Volume & & - \\
$\%$ Change in Total & 15 & - \\
Annual Cost & & \\
$\%$ Change in & 15 & \\
Unit Cost & &
\end{tabular}




\section{REFERENCES}

Abrams, C. S., R. P. Allen, E. A. Bracken, P. G. Hagan, and A. L. Taboas. 1980. Decontamination Research and Development Activities for the US DOE TRU Waste Management Program. RFP 3140, Rockwell International, Energy Sys tems Group, Golden, Colorado. Prepared for the Workshop on TRU Waste Washing, 19-20 Nov. 1980, Cadarache, France.

American Scientific Products. 1981-82. Catalog for Equipment and Supplies for Laboratories, McGaw Park, Illinois.

Brown, C. M. 1980. Economic Comparison of Centralizing or Decentralizing Processing Facilities for Defense Transuranic Waste, DOE/AL/TRU-8003, UL-70, Rockwell International Energy Systems Group, Golden, Colorado.

Copeland, G. L. and R. L. Heestand. 1980. "Volume Reduction of Contaminated Metal Waste." Metals and Ceramics Division, Oak Ridge National Laboratory. Paper presented at the 89th National Meeting of the American Institute of Chemical Eng ineers, August 17-20, 1980, Port land, Oregon.

Grant, E. L., W. G. Ireson and R. S. Leavenworth. 1976. Principles of Engineering Economy. 6th ed., The Ronald Press Company, New York.

Guthrie, K. M. 1974. Process Plant Estimating Evaluation and Control. Craftsman, Solana Beach, California.

Lyda, T. B. 1972. "How Much Working Capital Will the New Project Need?" Chemical Engineering, Sept. 18, 1972 pp. 182-188.

McCoy, M. W., R. P. Allen and H. W. Arrowsmith. 1980. Surface Decontamination of Solid Waste, PNL-SA-8368, Pac if ic Northwest Laboratory, Richland, Washington.

McCoy, M. W., H. W. Arrowsmith and R. P. Allen. 1980. Vibratory Finishing as a Decontamination Process. PNL-3336, Pacific Northwest Laboratory, Richland, Washington.

McMaster-Carr Supply Co. 1979. Mechanical Equipment Supply Catalog. Los Angeles, California.

Peters, M. S. and K. D. Timmerhaus. 1968. Plant Design and Economics for Chemical Engineers. 2nd ed. McGraw-Hill, New York.

Perrigo, L. D. 1970. "Influence of Design on Decontamination." In Decontamination of Nuclear Reactors and Equipment, ed. J. A. Ayres, pp. $\overline{230-259 .}$ The Ronald Press, New York. 
Richardson Engineering Services, Inc. 1981. Process Plant Construction Estimating Standards. Vol. 4, San Marcos, California.

U.S. Department of Energy (DOE). 1981. Spent Fuel and Radioactive Waste Inventories and Projections As of December 31, 1980. DOE/NE-0017, UC-70, Washington, D.C. 
APPENDIX A

LOW-INVENTORY, NONREACTOR NUCLEAR FACILITIES 
APPENDIX A

\section{LOW-INVENTORY, NONREACTOR NUCLEAR FACILITIES}

According to Backman et al. (1981): (a)

Many PNL-managed facilities contain low inventories of dispersible radioactive materials that are a necessary part of the programs conducted therein. The impact of an accident in these facilities would not be large to persons on the outside. A "low" inventory has been arbitrarily specified as the inventory of radioactive material that would be small enough to limit the consequences of a release to a maximum annual dose of 500 mrem to the critical organ of any individual located outside a facility should an accident occur within. The value of 500 mrem was selected as it is only $10 \%$ of the allowable radiation worker annual radiation dose limit to any critical organ. Also, the annual dose to an individual at the site boundary would be less than $50 \mathrm{mrem}$ and, therefore, less than $10 \%$ of the allowable maximum annual dose to a member of the public.

The inventories of radioactive materials involved in a release without exceeding the abovementioned dose are contained in Table A.1. If more than one radionuclide is present at a work site, the amount of radioactive material may not exceed a quantity calculated using a formula given in the referenced document, wherein the sum of ratios of the individual quantities to the allowable quantity is equal to or less than 1 . If the inventories of radionuclides were to be uncontrolled, the mobile facility might have to meet plutonium facility design requirements as given in Part II Buildings and Facilities Design, Section B - Plutonium Facilities, Facilities General Design Criteria, ERDA Appendix 6301. This document gives tornado and other wind and storm design requirements, seismic design requirements, and other requirements

(a) Backman, G. E., B. J. McMurray, N. P. Nisick and C. R. Richey. 1981. General Safety Assessment Document for PNL-Managed Nonreactor Nuclear Facilities. PNL-3280, Pacific Northwest Laboratory, Richland, Washington. 
TABLE A.1. Limits on Curie Inventory Qyantities for Radionuclides in Low-Inventory Facilities (a)

\begin{tabular}{|c|c|c|}
\hline Radionuclide & Inventory, cur ies & Inventory, grams \\
\hline${ }^{3} \mathrm{H}$ & 2,100 & $2.2 \times 10^{-1}$ \\
\hline${ }^{60} \mathrm{Co}$ & 850 & $7.5 \times 10^{-1}$ \\
\hline${ }^{85} \mathrm{Cr}$ & 170,000 & $4.3 \times 10^{2}$ \\
\hline${ }^{89} \mathrm{Sr}$ & 2,100 & $7.3 \times 10^{-2}$ \\
\hline${ }^{90} \mathrm{Sr}$ & 550 & 3.8 \\
\hline${ }^{99} \mathrm{Tc}$ & 6,500 & $3.8 \times 10^{5}$ \\
\hline${ }^{106} \mathrm{Ru}$ & 480 & $1.4 \times 10^{-1}$ \\
\hline${ }^{129} \mathrm{I}$ & 0.24 & $1.5 \times 10^{3}$ \\
\hline $131_{\mathrm{I}}$ & 1.1 & $8.9 \times 10^{-6}$ \\
\hline${ }^{137} \mathrm{Cs}$ & 7,500 & $7.6 \times 10$ \\
\hline${ }^{144} \mathrm{Ce}$ & 550 & $1.7 \times 10^{-1}$ \\
\hline${ }^{226} \mathrm{Ra}$ & 3.2 & 3.3 \\
\hline $235 U$ & 7.5 & $3.5 \times 10^{6(b)}$ \\
\hline $238 U$ & 8.0 & $2.4 \times 10^{7}$ \\
\hline $237 \mathrm{~Np}$ & 1.8 & $2.6 \times 10^{3}$ \\
\hline${ }^{238} \mathrm{Pu}$ & 1.5 & $8.9 \times 10^{-2}$ \\
\hline${ }^{239} \mathrm{Pu}$ & 1.7 & $2.8 \times 10$ \\
\hline $240_{\mathrm{Pu}}$ & 1.7 & 7.5 \\
\hline${ }^{24} 1_{\mathrm{Pu}}$ & 850 & 7.5 \\
\hline${ }^{241} \mathrm{Am}$ & 1.5 & $4.6 \times 10^{-1}$ \\
\hline${ }^{243} \mathrm{Cm}$ & 1.5 & $3.6 \times 10^{-2}$ \\
\hline${ }^{244} \mathrm{Cm}$ & 1.5 & $1.8 \times 10^{-1}$ \\
\hline
\end{tabular}

(a) Backman, G. E., et a 1. 1981.

(b) Although a facjlity may have less than threshold quantities of $235 \mathrm{U}$ in the form of enriched uranium, it is classified as a Principal Nonreactor Nuclear Facility if the amount of enriched material exceeds $45 \%$ of a minimum critical mass, i.e., a Fissionable Material Facility. 
to assure that the design of the facility will protect the public and operating personnel from hazards associated with normal plutonium operations or design basis accident (DBA) conditions.

At this stage of evaluating a mobile, trailer-contained, vibratory finishing decontamination facility, it appears impractical for the facility to meet requirements other than those of low-inventory nonreactor nuclear facilities; i.e., the radionuclides must be controlled to below the quantities given in Table A.1.

An example of TRU-contaminated material that may be processed in a mobile vibratory finishing facility is the metal scrap stored at the Idaho National Engineering Laboratory (Abrams et al. 1980). This stored metal scrap, with a density of $26 \mathrm{lb} / \mathrm{ft}^{3}$, has a ${ }^{239} \mathrm{Pu}$ content of $0.090 \mathrm{~g} / \mathrm{ft}^{3}$. If this scrap were sectioned (and no decontamination assumed) and placed into 55-gal drums so that a drum would contain $300 \mathrm{lb}$ of the waste, the drum would then contain about $1 \mathrm{~g}{ }^{239} \mathrm{Pu}$. If the equivalent of the TRU contaminants from 10 drums of waste were in the vibratory finishing facility, about $10 \mathrm{~g}$ of ${ }^{239} \mathrm{Pu}$ would be present, whereas the control level in Table A.1 is $28 \mathrm{~g}$ for a low-inventory facility. Thus, administrative controls of curie inventories apparently can be reasonably achieved without overburdening operations of the facility. 
APPENDIX B

COSTS FOR A FIXED VIBRATORY FINISHING FACILITY 
APPENDIX B

\section{COSTS FOR A FIXED VIBRATORY FINISHING FACILITY}

Both the capital and operating costs for a fixed facility for vibratory finishing of TRU-contaminanted metallic and nonmetalic materials can differ depending on whether a new building is required or unoccupied space in an existing low-inventory nonreactor nuclear facility can be used. Rough estimates, intended to illustrate possible fixed facility costs, are given below.

\section{FIXED FACILITY CAPITAL COST ESTIMATES}

A cursory look has been taken of a facility in which existing unoccupied space is used. It is assumed for this case that the space would be adjacent to other working areas and that utilities and services, such as HVAC, would be available. No capital cost for a building would be required; the only capital requirement would be that for process equipment and installation and for working capital. A contingency of $40 \%$ is used as there are many unknowns in this case. Capital costs for this facility based upon those in Table 3 are below.

$\begin{array}{lr}\text { Process Equipment } & \$ 421,000 \\ \text { Contingency a 40\% } & 168,000 \\ \text { Fixed Capital Cost } & \$ 589,000 \\ & \\ \text { Working Capital } & \\ \quad(2 \text { month Operating Cost) } & \frac{45,000}{\$ 634,000} \\ \text { Total Capital Cost } & \end{array}$

\section{FIXED FACILITY OPERATING COST ESTIMATE}

In the mobile facility, two workers are required to be in the unit; this is not an operating need, but a safety requirement. The supervisor and a radiation monitor would have to spend more time with the isolated mobile facility than with a fixed facility adjacent to other work areas, primarily 
because of travel between locations. Consequently, the amount of labor required for a fixed facility would be half that needed for a mobile facility. This is reflected in estimated operating costs given in Table B.1.

Maintenance and repair costs for a fixed facility would also be less than those for a mobile facility since there would be no additional, or at least very minimal, building maintenance costs. Costs for utilities, LLW disposal, and TRU geologic disposal would be identical for both the mobile and fixed facilities.

Process materials costs would be the same for the mobile or fixed facility, except for protective clothing and laundry, which are directly associated with the number of workers involved and their need to periodically leave the facility. Since the fixed facility would have full services, the single worker assigned full time to vibratory finishing would have less need to change clothing, as also would the supervisor and radiation monitor. The latter costs

\section{TABLE B.1. Fixed Facility Operating Cost}

Labor

Maintenance and Repair

Process Materials

Chemical concentrate

Metal vibratory finisher media

Filter cartridges

Port land cement

Drums (55-gal)

Protective clothing-laundry

Operating supplies

Utilities

Water

Electricity

LLW Disposal

TRU Geologic Disposal

Subtotal (rounded)

Contingency (25\%)

Total Operating Cost
$\$ 106,000$

35,000

5,100

2,000

300

17,500

800

10,000

negligible

3,300

24,000

$\frac{12,000}{\$ 217,000}$

$\frac{54,000}{\$ 271,000}$ 
prorated for all operations in the building. It was assumed that the equivalent of 2-3/4 changes of clothing per day could be charged to the vibratory finishing operation.

Based upon the above assumptions, the total operating cost for vibratory finishing in a fixed facility would be about $\$ 271,000$.

\section{ANNUAL COSTS}

The same equation as in the body of the report was used to determine capital recovery or annual capital costs. The values for the equation are $P=$ $\$ 634,000, L=\$ 74,000(\$ 29,000$ as salvage value at $5 \%$ of initial fixed capital cost and $\$ 45,000$ as working capital recovered as end of facility life), $i^{*}=$ $10 \%$ (discount rate), $n=11$ yr (facility life), and the capital recovery factor $(A / P)_{j *, n}=0.15396$. The annual capital cost was calculated to be $\$ 94,000$.

The estimated total annual cost and unit cost for vibratory finishing TRUcontaminated metallic and nonmetallic materials are below:

$\begin{array}{lr}\text { Annual Operating Cost } & \$ 271,000 \\ \text { Annual Capital Cost } & \frac{94,000}{} \\ \text { Total Annual Cost } & \$ 365,000 \\ \text { Unit Cost, } & 58 \\ \$ / \mathrm{ft}^{3} \text { (reduced volume) } & 6.70 \\ \$ / \mathrm{ft}^{3} \text { (original volume }{ }^{\mathrm{a}} \text { ) } & \end{array}$

The total annual cost and unit cost for a fixed facility are about $60 \%$ of similar costs for the mobile facility. This is due to substantially less capital investment and labor cost.

(a) Based on the reference glove box described by Abrams et al. (1980). 


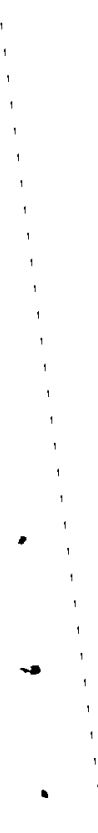




\section{STRIBUTION}

No. of

Copies

OFFSITE

27 DOE Technical Information Center

R. E. Cunningham

Office of Nuclear Safety Materials and Safeguards

Room 562

Nuclear Regulatory Commission

7915 Eastern Avenue

Silver Springs, MD 20910

J. B. Martin

Division of Waste Management

Nuclear Regulatory Commission

Washington, DC 20555

R. Dale Smith

Division of Waste Management

Nuclear Regulatory Comm ission

Washington, DC 20555

W. E. Mott

DOE Division of Environmental Control Technology

Washington, DC 20545

C. R. Cooley

DOE Nuclear Waste Management Programs

NE30, B-107, HQ

Washington, DC 20545

G. H. Daly

DOE Nuclear Waste Management Programs

NE30, B-107, HQ

Washington, DC 20545

E. G. Delaney

DOE Nuclear Waste Management Programs

NE30, B-107, HQ

Washington, DC 20545
No. of

Copies

J. E. Dieckhoner

DOE Nuclear Waste Management Programs

NE30, B-107, HQ

Washington, DC 20545

C. H. George

DOE Nuclear Waste Management Programs

NE30, B-107, HQ

Washington, DC 20545

C. A. Heath

DOE Nuclear Waste Management Programs

NE30, B-107, HQ

Washington, DC 20545

A. F. Kluk

DOE Nuclear Waste Management Programs

NE30, B-107, HQ

Washington, DC 20545

M. L. Lawrence

DOE Nuclear Waste Management Programs

NE30, B-107, HQ

Washington, DC 20545

D. J. McGoff

DOE Nuclear Waste Management Programs

NE30, B-107, HQ

Washington, DC 20545

S. Meyers

DOE Nuclear Waste Management Programs

NE30, B-107, HQ

Washington, DC 20545 
No. of

Copies
No. of

Copies

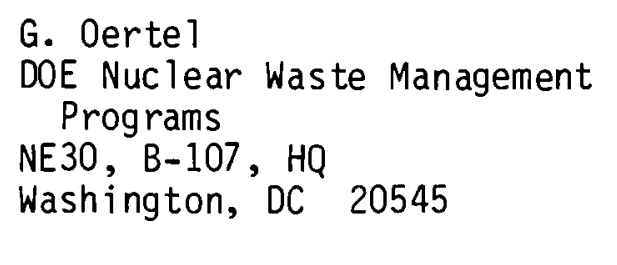

\section{A. F. Perge}

DOE Nuclear Waste Management Programs

NE30, B-107, HQ

Wash ington, DC 20545

R. W. Ramsey, Jr.

DOE Nuclear Waste Management Programs

NE30, B-107, HQ

Washington, DC 20545

D. L. Vieth

DOE Nuclear Waste Management Programs

NE30, B-107, HQ

Washington, DC 20545

R. D. Walton

DOE Nuclear Waste Management Programs

NE30, B-107, HQ

Washington, DC 20545

F. F. Gorup

DOE Chicago Operations and Region Office

Argonne, IL 60439

M. Littleton

DOE Idaho Operations Office

550 2nd Street

Idaho Falls, ID 83401

J. Coobs

ORNL/Union Carbide

P.0. Box X, B Idg. 3047

Oak Ridge, TN 37830

P. Owen

Oak Ridge National Laboratory

P.0. Box X, Bldg. 2001

Oak Ridge, TN 37830
J. Al exander

DOE Oak Ridge Operations Office

P.0. Box E

Oak Ridge, TN 37830

D. Brown

DOE Oak Ridge Operations Office P.0. Box E

Oak Ridge, TN 37830

L. Keller

DOE Oak Ridge Operations Office

P.0. Box E

Oak Ridge, TN 37830

A. M. Valentine

Los Alamos Scientific Laboratory

P.0. Box 1663

Los Alamos, NM 87544

W. Lawless

DOE Savannah River Operations Office

P.0. Box A

Aiken, SC 29801

R. H. Meservey

EG\&G Idaho

P.0. Box 1625

Idaho Falls, ID 83415

L. Lanni

DOE San Francisco Operations

1333 Broadway

Oakland, CA 94612

D. D. Monette

DOE Albuquerque Operations Office P.0. Box 5400

Albuquerque, NM 87185

D. V. Eckman

U.S. Department of Energy

Dayton Area Office

P.0. Box 66

Miamisburg, $\mathrm{OH} 45327$ 
J. G. Theme 1 is

U.S. Department of Energy

P.0. Box 2567

Grand Junction, CO 81502

J. Reed

U.S. Department of Energy

P.0. Box 14100

Las Vegas, NV 89114

Bever ly Rawles

Battelle Memorial Institute

Office of Nuclear Waste I solation

$505 \mathrm{King}$ Avenue

Columbus, $\mathrm{OH} 43201$

W. S. Bennett

Rockwe 11 International

Rocky Flats Plant

P.0. Box 464

Golden, CO 80401

E. Vejvoda

Rockwe 11 International

Rocky Flats Plant

P.0. Box 464

Golden, CO 80401

C. C. Connors

Rockwe 11 International

8900 DeSoto Avenue

Canoga Park, CA 91304

W. D. Gisler

Bend ix Field Engineering Corporation

P.0. Box 1569

Grand Junction, CO 81502

E. R. Sorom

Reynolds Engineering \&

Electric Co.

P.0. Box 14400

Las Vegas, NV 89114

R. Rudolph

Bechtel National Incorporated

P.0. Box 350

Oak Ridge, TN 37830
0. Towler, Jr.

E. I. du Pont de Nemours Company Savannah River Laboratory

Aiken, SC 29801

R. Maher

E. I. du Pont de Nemours Company Savannah River Laboratory

Aiken, SC 29801

R. Williams

Electric Power Research Institute 3412 Hillview Avenue

P.0. Box 10412

Palo Alto, CA 94304

Environmental Protection Agency

Technological Assessment Division (AW-559)

Office of Radiation Programs

U.S. Environmental Protection Agency

Washington, DC 20460

E. Kurtz

Genera 1 Electric Company

P.0. Box 508

Sunnyvale, CA 94086

T. C. Elswick

Monsanto Research Corporation

Mound Facility

Miamisburg, $\mathrm{OH} 45342$

J. P. Duckworth

Plant Manager

Nuclear Fuels Services, Inc.

P.0. Box 124

West Valley, NY 14171

ONSITE

11 DOE Richland Operations Office

E. A. Bracken

P. A. Craig

0. J. Elgert 
No. of

Copies

R. E. Gerton

J. L. Landon

H. E. Ransom

J. J. Schreiber

M. W. Shupe

H. R. Tolman

J. D. White

J. M. Usher

6 Rockwe 11 Hanford Operations

J. L. Deichman

W. F. Heine

C. M. Manry

J. H. Roecker

D. D. Wodrich

File Copy

7 UNC United Nuclear Industries

J. S. Brehm

T. E. Dabrowski

D. Doerge

A. J. Eirich

G. F. Jones

W. J. Kyriaz is

B. W. Math is

Westinghouse Hanford Company

A. G. Blasewitz
No. of

Copies

62 Pacific Northwest Laboratory

R. P. Allen (10)

R. L. Brodzinsk $i$

H. L. Butts

L. K. Fetrow

V. F. FitzPatrick

R. M. Fleischman

J. M. Halter/R. G. Sullivan

K. M. Harmon/J. A. Kelman

R. F. Hazelton (20)

J. H. Jarrett

A. B. Johnson, Jr.

M. R. Kreiter

L. T. Lakey

J. M. Latkovich

R. C. Liikala

R. P. Marsha 11

M. W. McCoy (5)

J. L. McElroy

J. V. Robinson

W. A. Ross

J. M. Rusin/R. A. Brouns

K. J. Schneider/R. E. Rhoads

A. I. Smith

Technical Information (5)

Publishing Coordination (2) 